Article

\title{
Field Measurements of Residential Energy Consumption and Indoor Thermal Environment in Six Chinese Cities
}

\author{
Tianchi Hu *, Hiroshi Yoshino and Jie Zhou
}

Graduate School of Engineering, Tohoku University, Aoba 6-6-11-1201, Sendai 980-8579, Japan; E-Mails: yoshino@sabine.pln.archi.tohoku.ac.jp (H.Y.); zhoujie8558thk@hotmail.com (J.Z.)

* Author to whom correspondence should be addressed; E-Mail: tchhu69@yahoo.com; Tel.: +81-22-795-7885; Fax: +81-22-795-7886.

Received: 9 January 2012; in revised form: 10 May 2012 / Accepted: 21 May 2012 /

Published: 19 June 2012

\begin{abstract}
The purpose of this study was to reveal the energy use and indoor environment characteristics of twelve households located in six cities in China, including daily use of gas and electricity, temperature and humidity throughout a year. The energy uses for district heating and hot water were not included. The investigated houses were separated into two groups, namely Group 1 with domestic heating, and Group 2 with district heating. The analysis showed that the energy use of Lighting and Audio visual \& information for each house is not very different during the four seasons. Annual energy use varied from 13.3 to 32.4 GJ in Group 1. The energy use of House 05 was $32.4 \mathrm{GJ} /$ year, which is the highest in Group 1, the space heating reached $18.5 \mathrm{GJ} /$ year, accounting for $57 \%$ of the total. Energy use of House 01 increased in winter and summer, which is attributed to the use of heating in winter and cooling in summer, respectively. Annual energy use varied from 2.9 to $17.0 \mathrm{GJ}$ in Group 2. Almost no change of energy use was found for the houses in Group 2 during the four seasons, but a big difference of average indoor temperature was found in the coldest days between the houses in Group 1 (around $10^{\circ} \mathrm{C}$ ) and Group 2 (around $20^{\circ} \mathrm{C}$ ), while the difference was small in summer.
\end{abstract}

Keywords: field measurement; energy use; thermal environment; China 


\section{Introduction}

Residential energy use in China has been increasing significantly with the rapid growth of the economy and the parallel improvement of living standards. This rapid increase of energy use leads to serious environment problems such as global warming, air pollution and acid rain. In 2007, the residential sector in China used 308.1 million tons of standard coal, making it the second highest among all sectors [1]. Urban households accounted for $63 \%$ of the total residential energy use in 2007 [2]. The average family size in China dropped from 5.2 persons in 1981 to 3.04 persons per family in 2002, a trend of that is expected to continue. Meanwhile, the urban population is expected to grow by 20 million every year and this increase in the total number of families in the region, together with the increase in living area, will multiply the contribution of energy use from families. The residential energy use could more than double by 2020, from 6.6 EJ in 2000 to 15.9 EJ in 2020 [3]. In order to solve the problems of balance among natural environment, growth of economy and energy use, it is necessary to understand the actual and detailed situation of energy use and the indoor thermal environment, so as to estimate the future residential indoor thermal environment requirements and energy use trends, and the possibilities and strategies of energy conservation in China $[4,5]$.

Some research has been undertaken to understand the current status of residential energy consumption and the thermal environment in China. Yoshino et al. [6,7] investigated the energy use and indoor thermal environment of residential buildings in seven Chinese cities. It was found that air-conditioning units were popular for space heating in $45 \%$ of households in Shanghai, while the heating system was not operated all day long in some cases, although central space heating was popular in Harbin. The average energy uses of Chongqing and Changsha are higher than others, with $23.3 \mathrm{GJ} /$ year and 21.2 GJ/year, respectively. Lam [8] conducted a survey on energy consumption in five different types of residential buildings in Hong Kong, and estimated the electricity end use values. It was found that air-conditioners, refrigerators and lighting were the three main consumers. In two other studies by Yoshino et al. [9] and Zhang and Yoshino [10] through a questionnaire survey, the results showed that indoor environment was not so severe in Xi'an, whereas the indoor temperature and humidity in Hong Kong and Shanghai were high. During winter seasons, indoor humidity was too low with the relative humidity fell below $20 \%$ in Urumqi and Beijing where houses were equipped with central heating systems. During the summer months, the absolute humidity of many houses in Shanghai, Changsha, Chongqing and Hong Kong, was found to be higher than the maximum acceptable humidity value.

However, the characteristics of energy use and indoor environment in China cannot be comprehensively determined because yearly daily energy use and indoor environment measurement data in the field is still lacking. To address this gap, field measurement investigations were carried out in 12 Chinese houses (apartments) of six cities distributed in three climate areas. This research adopted a uniform method of investigation to guarantee the comparability of the results and the subsequent analysis of the data. It aimed to understand the detailed characteristics (end use) of residential energy use and indoor thermal environment in six Chinese cities. Though the sample size is not large, this research should be helpful for preliminary understanding the detailed characteristics of urban residential energy use and indoor environment in China. No such research has been reported before. 


\section{Outline of the Survey}

\subsection{Object of the Survey}

The survey was conducted in the urban areas of Harbin, Shenyang, Dalian, Beijing, Shanghai, and Changsha. The investigated cities are all major cities in China and are distributed in three climate zones [11]. Figure 1 shows the location of investigated cities. Harbin and Shenyang are located in the very cold-climate area of China (outdoor average temperature of coldest month $\leq-10{ }^{\circ} \mathrm{C}$ ), Dalian and Beijing are situated at the northern part of China categorized as the cold area (outdoor average temperature of coldest month $0{ }^{\circ} \mathrm{C} \sim-10{ }^{\circ} \mathrm{C}$ ), whereas Shanghai, and Changsha belong to the hot summer \& cold winter area of China (outdoor average temperature of coldest month is $0{ }^{\circ} \mathrm{C} \sim-10{ }^{\circ} \mathrm{C}$ and average temperature of the hottest month is $25^{\circ} \mathrm{C} \sim 30^{\circ} \mathrm{C}$ ). Table 1 presents an overview of the twelve typical investigated residences, including floor area, number of family members, energy sources of apparatus and measurement period. The 12 houses are separated into two groups, Group 1 (Houses 01-05) which used domestic heating (House 05 used a gas central heating system), and Group 2 (Houses 06-12) which used district heating. They were selected by the researchers of local universities, and are typical houses (apartments) in the investigated cities. All houses used gas for cooking and Houses 01-06 used electricity for cooling. The Houses 01, 02, 05, 06 and 11 used reinforced concrete as building structure, and the other houses used brick concrete as building structure. The investigated families have middle-income.

Figure 1. Location of the field measurement.

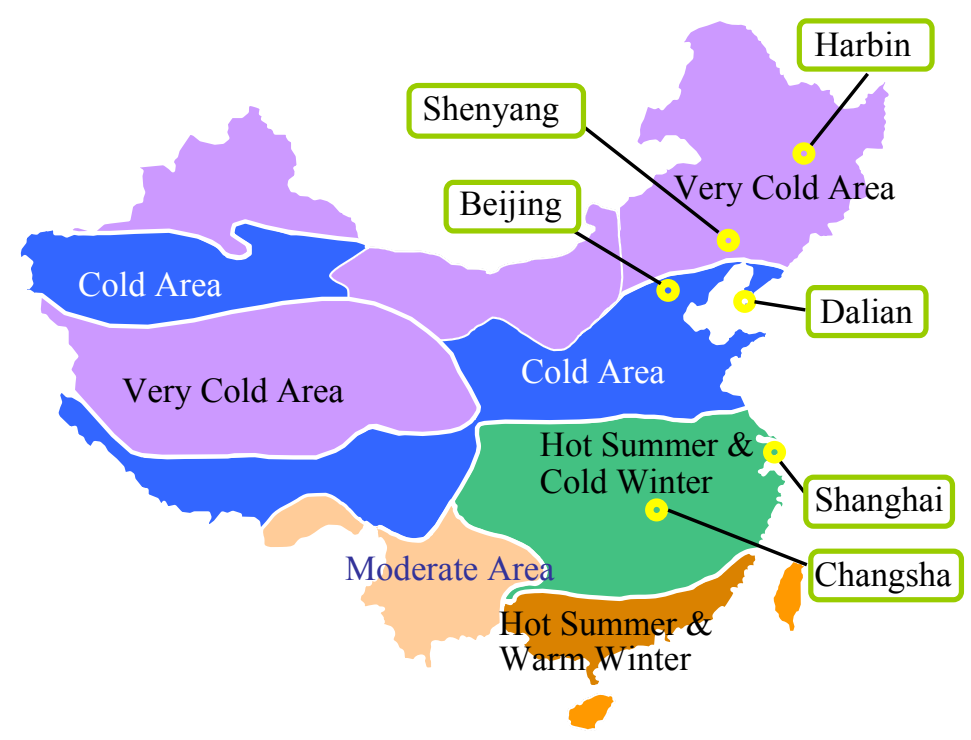

Table 1. Houses of the survey.

\begin{tabular}{ccccccccccc}
\hline \multirow{2}{*}{ Group } & House & \multirow{2}{*}{ City } & \multicolumn{2}{c}{ Floor area } & Family & \multicolumn{4}{c}{ Energy source } & Measured \\
\cline { 7 - 9 } & No. & & $\mathbf{m}^{\mathbf{2}} \mathbf{)}$ & members & Heating & Cooling & Hot water & Cooking & period \\
\hline \multirow{4}{*}{ Group 1 } & 01 & Shanghai & 129.6 & 4 & Electricity & Electricity & Gas & Gas & $2006.12-2007.12$ \\
& 02 & Shanghai & 130.0 & 3 & Electricity & Electricity & District & Gas & $2006.12-2007.12$ \\
& 03 & Changsha & 106.0 & 4 & Electricity & Electricity & Electricity & Gas & $2006.12-2007.12$ \\
& 04 & Changsha & 103.0 & 3 & Electricity & Electricity & Gas & Gas & $2006.12-2007.12$ \\
& 05 & Beijing & 80.5 & 3 & Gas & Electricity & Gas & Gas & $2008.1-2009.1$ \\
\hline
\end{tabular}


Table 1. Cont.

\begin{tabular}{|c|c|c|c|c|c|c|c|c|c|}
\hline \multirow{2}{*}{ Group } & \multirow{2}{*}{$\begin{array}{c}\text { House } \\
\text { No. }\end{array}$} & \multirow{2}{*}{ City } & \multirow{2}{*}{$\begin{array}{c}\text { Floor area } \\
\left(\mathbf{m}^{2}\right)\end{array}$} & \multirow{2}{*}{$\begin{array}{c}\text { Family } \\
\text { members }\end{array}$} & \multicolumn{4}{|c|}{ Energy source } & \multirow{2}{*}{$\begin{array}{c}\text { Measured } \\
\text { period }\end{array}$} \\
\hline & & & & & Heating & Cooling & Hot water & Cooking & \\
\hline \multirow{7}{*}{ Group 2} & 06 & Beijing & 90.0 & 3 & District & Electricity & Gas & Gas & 2008.1-2009.1 \\
\hline & 07 & Dalian & 101.4 & 2 & District & No use & Solar & Gas & 2008.1-2009.1 \\
\hline & 08 & Dalian & 89.0 & 4 & District & No use & Electricity & Gas & 2008.1-2009.1 \\
\hline & 09 & Shenyang & 110.0 & 5 & District & No use & Electricity & Gas & 2008.2-2009.2 \\
\hline & 10 & Shenyang & 100 & 3 & District & No use & Electricity & Gas & 2008.2-2009.2 \\
\hline & 11 & Harbin & 180.5 & 3 & District & No use & District & Gas & $2007.1-2008.1$ \\
\hline & 12 & Harbin & 104.0 & 3 & District & No use & Electricity & Gas & 2007.1-2008.1 \\
\hline
\end{tabular}

\subsection{Method of Measurement}

Table 2 and Figure 2 show the measurement methods and apparatus used. The energy use of electricity for each household was recorded at one minute intervals, by the household energy use recording system. Energy consumption of gas was measured by a camera type color image data logger. This data logger photographed the gas readings in an interval of 5 minutes. The difference between the two shots within five minutes was the volume of gas consumed within every 5 minutes, and the use of gas was calculated based on the exothermic conversion values shown in Table 3 . The values were provided by the gas company in each city, and the values are different since the different companies use different energy sources to produce city gas. Measurement points were placed in the living room and master bedroom of the household, and outdoors. Figure 3 shows the categories of energy use and the locations of measurements taken in House 01 as an example. Houses 01, 04, 05 and 06 used gas for both cooking and hot water, but cooking and hot water shared a gas meter, thus the gas use cannot be divided into use for cooking and hot water.

Table 2. Measurement of methods.

\begin{tabular}{llll}
\hline Methods & Measurement & Time interval & Location \\
\hline $\begin{array}{l}\text { Home energy consumption } \\
\text { recording system }\end{array}$ & Electricity consumption & $1 \mathrm{~min}$ & \\
$\begin{array}{l}\text { Camera type color image data } \\
\text { Small sensor \& data logger }\end{array}$ & $\begin{array}{l}\text { Gas consumption } \\
\text { Temperature \& relative humidity }\end{array}$ & $\begin{array}{l}5 \mathrm{~min} \\
30 \mathrm{~min}\end{array}$ & $\begin{array}{l}\text { Kitchen } \\
\text { Outdoors \& Living } \\
\text { room \& Bedroom }\end{array}$ \\
\hline
\end{tabular}

Figure 2. Measurement items.
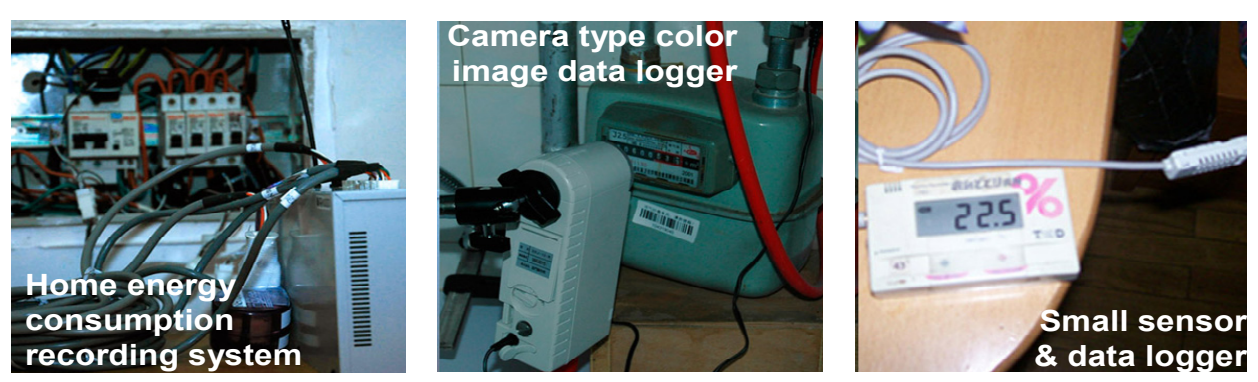
Table 3. Energy conversion values of energy sources.

\begin{tabular}{llc}
\hline Energy source & City & Calorific values of units \\
\hline Electricity & All & $3.6 \mathrm{MJ} / \mathrm{kWh}$ \\
Gas & Shanghai & $14.5 \mathrm{MJ} / \mathrm{m}^{3}$ \\
& Changsha & $36.0 \mathrm{MJ} / \mathrm{m}^{3}$ \\
& Harbin & $16.8 \mathrm{MJ} / \mathrm{m}^{3}$ \\
& Beijing & $38.6 \mathrm{MJ} / \mathrm{m}^{3}$ \\
& Dalian & $16.2 \mathrm{MJ} / \mathrm{m}^{3}$ \\
& Shenyang & $27.3 \mathrm{MJ} / \mathrm{m}^{3}$ \\
\hline
\end{tabular}

Figure 3. Location of measurement instruments and categories of energy use in House 01.

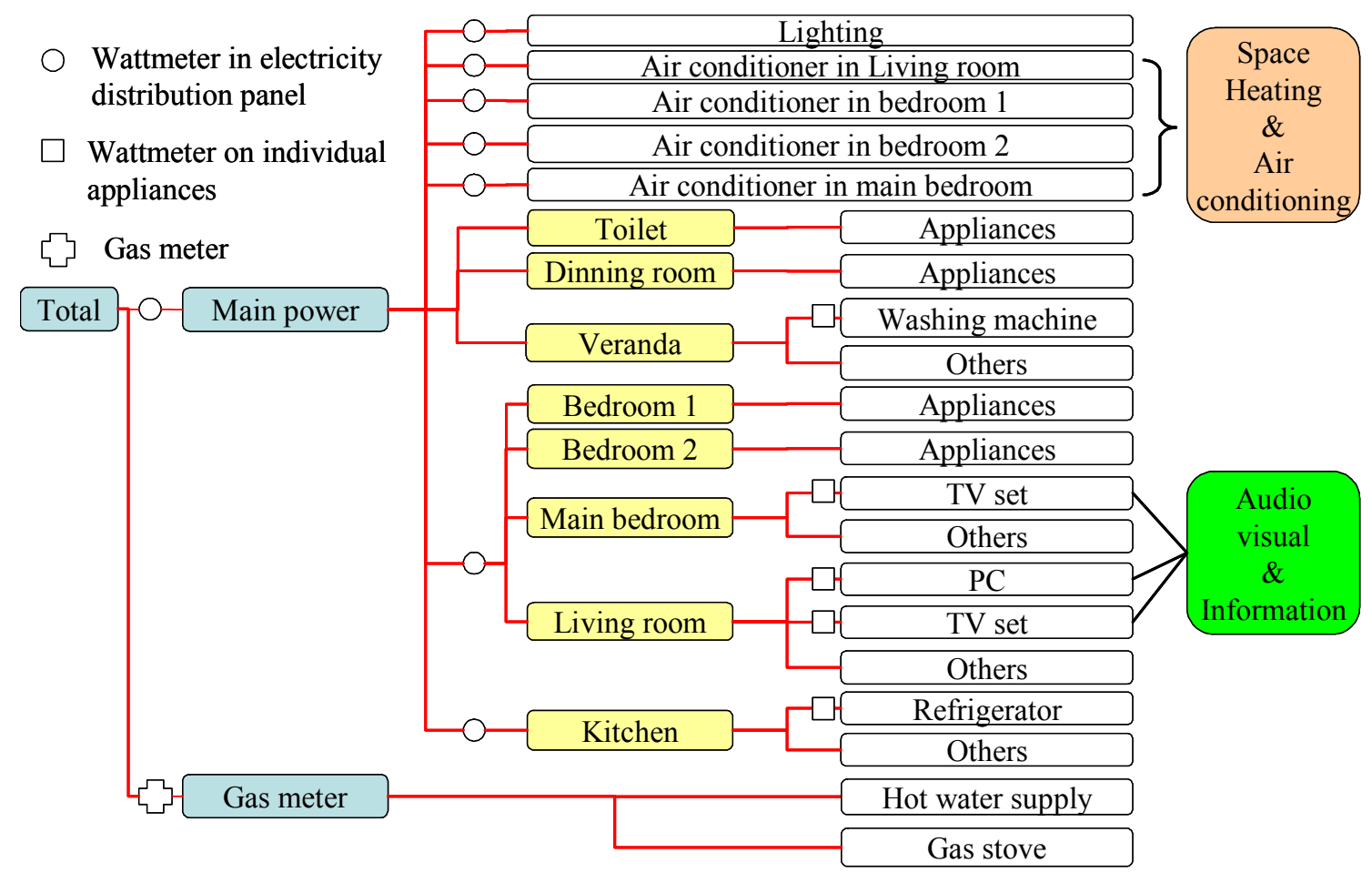

\section{Results and Discussion}

\subsection{Annual Energy Consumption}

Figure 4 shows the annual energy use of the twelve investigated houses. The energy use for district heating was not included in the houses of Group 2. The energy use for hot water of Houses 02 and 11 are not included either, since these houses used a district central hot water system. House 07 used a solar water heater (consuming electricity when the solar energy was not enough). House 05 in Beijing consumed 32.4 GJ in a year (the largest in Group 1), in which cooking \& hot water and space heating used 7.8 and 18.5 , accounting for $24 \%$ and $57 \%$ of the total energy use, respectively, while its energy use of cooling was the least in Group 1. The energy use for heating was almost nine times that for cooling. It is clear that energy use for heating in House 05 is the largest in Group 1, and this is the reason why the energy use of House 05 is the largest. The second largest consumer is House 01, where various kind of housing equipment is used. The other reason is that this family is relatively rich. House 09 consumed 17.0 GJ, which is the largest in Group 2. One of the reasons is that it has the largest floor 
area and number of family members in Group 2. Houses 06, 08, 09 and 12 used more energy than others in Group 2 since they used domestic hot water. The average energy use for hot water was 3.5 GJ among the houses with domestic hot water, accounting for $22 \%$ of the total energy use. The average energy use of washing machines in the investigated houses was $0.1 \mathrm{GJ}$, accounting for $1 \%$ in the total energy use. It is the smallest part in total energy use. The energy use of the washing machine in House 11 was three times the average energy use since its washing machine had a special function to warm up the water. House 06 in Beijing used 2.2 GJ for a fish tank, accounting for $19 \%$ of its total energy use. The average energy use for refrigerator and audio \& information in the 12 investigated houses was about $1.6 \mathrm{GJ}$ and $1.7 \mathrm{GJ}$, accounting for $10 \%$ and $11 \%$, respectively. The average energy used for lighting was $0.5 \mathrm{GJ}$ in the 12 houses, accounting for $3.4 \%$ in the total energy use, which was second smallest part in the total energy use.

Figure 4. Energy consumption in a year.

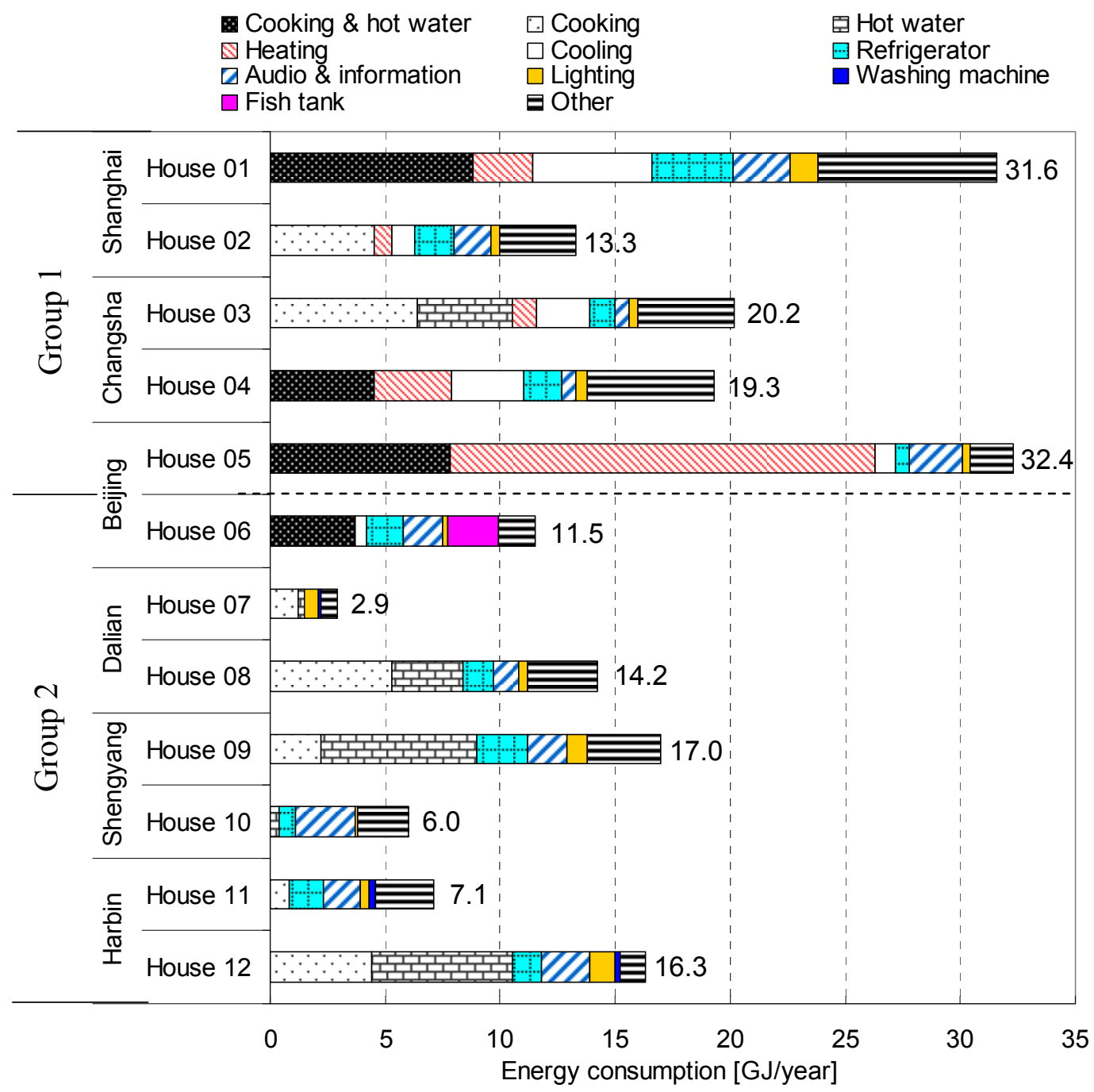

It can be seen that House 08 used 3.1 GJ for hot water, while House 07 only used 0.3 GJ. The former number is ten times the latter. The main reason is that House 07 is equipped with a solar water heater. Another reason is that the number of family members in House 07 ( $c f$. Table 1) is less than in House 08 (the floor area of House 07 is larger than House 08, the building structure is same, and the 
annual income in House 07 is higher than House 08). The energy use of House 07 was the least in Group 2. Besides the reason that House 07 used a solar water heater and it had the smallest family size, the other reason is that the occupants did not use a refrigerator or audio \& information in the year.

\subsection{Daily Year-Round Energy Consumption and Temperature}

Houses 01, 05 which used domestic heating and House 08 which used district heating were selected for analysis. Energy used for cooling in House 01 was the largest in Group 1, energy used for heating in House 05 was the largest in Group 1, and House 08 used 14.2 GJ/year, almost the same as the average value of energy use among Houses 06, 08, 09 and 12 (14.7 GJ/year) in Group 2, as shown in Figure 4. Figure 5 illustrates the daily year-round energy uses for end use and temperatures of these houses.

Figure 5. Daily year-round energy use and temperature of Houses 01 (a), 05 (b) and 08 (c). Note: (Bottom to top) Other, Lighting, Audio visual \& information, Refrigerator, Hot water, Cooking, Space cooling/heating.

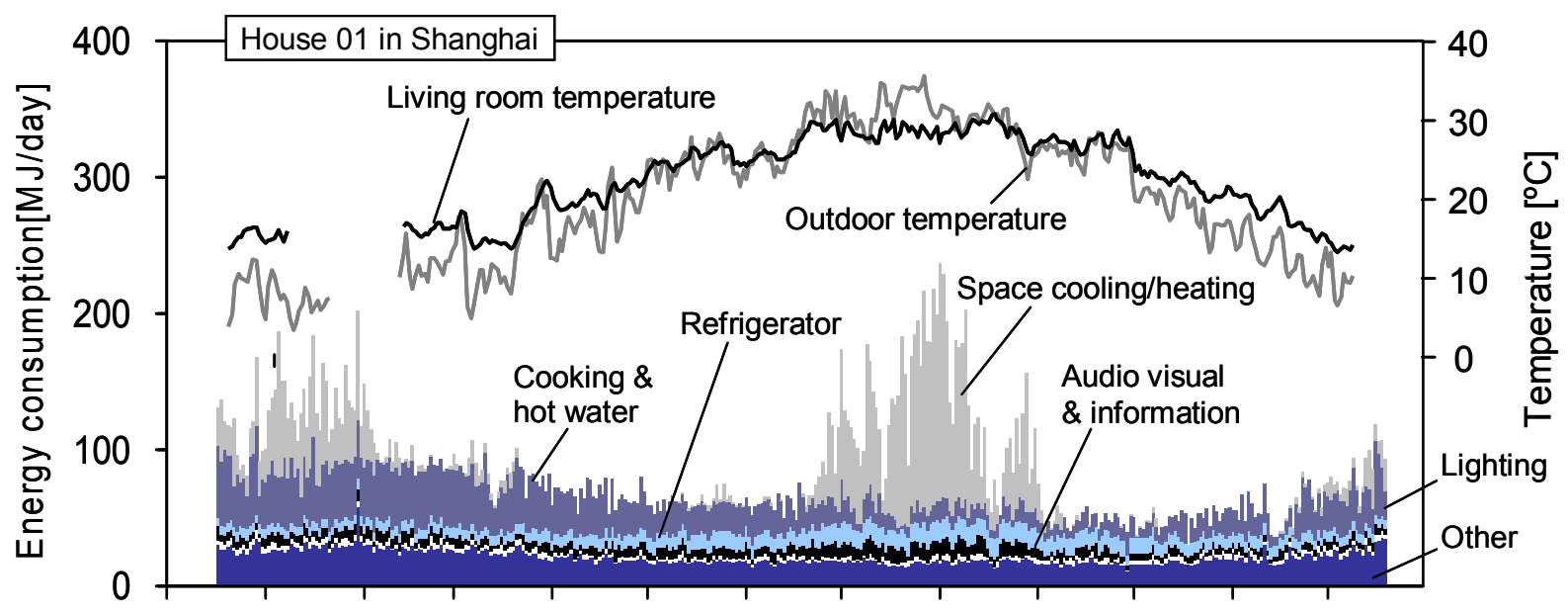

(a)

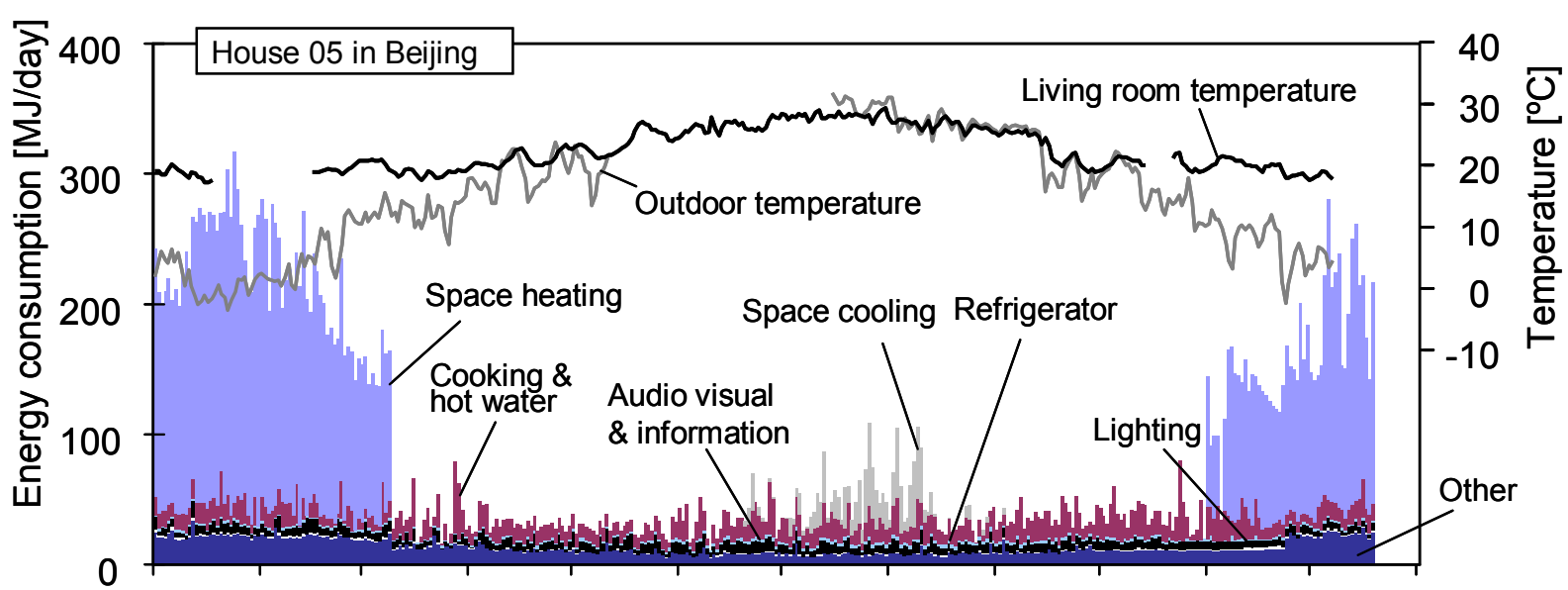

(b) 
Figure 5. Cont.

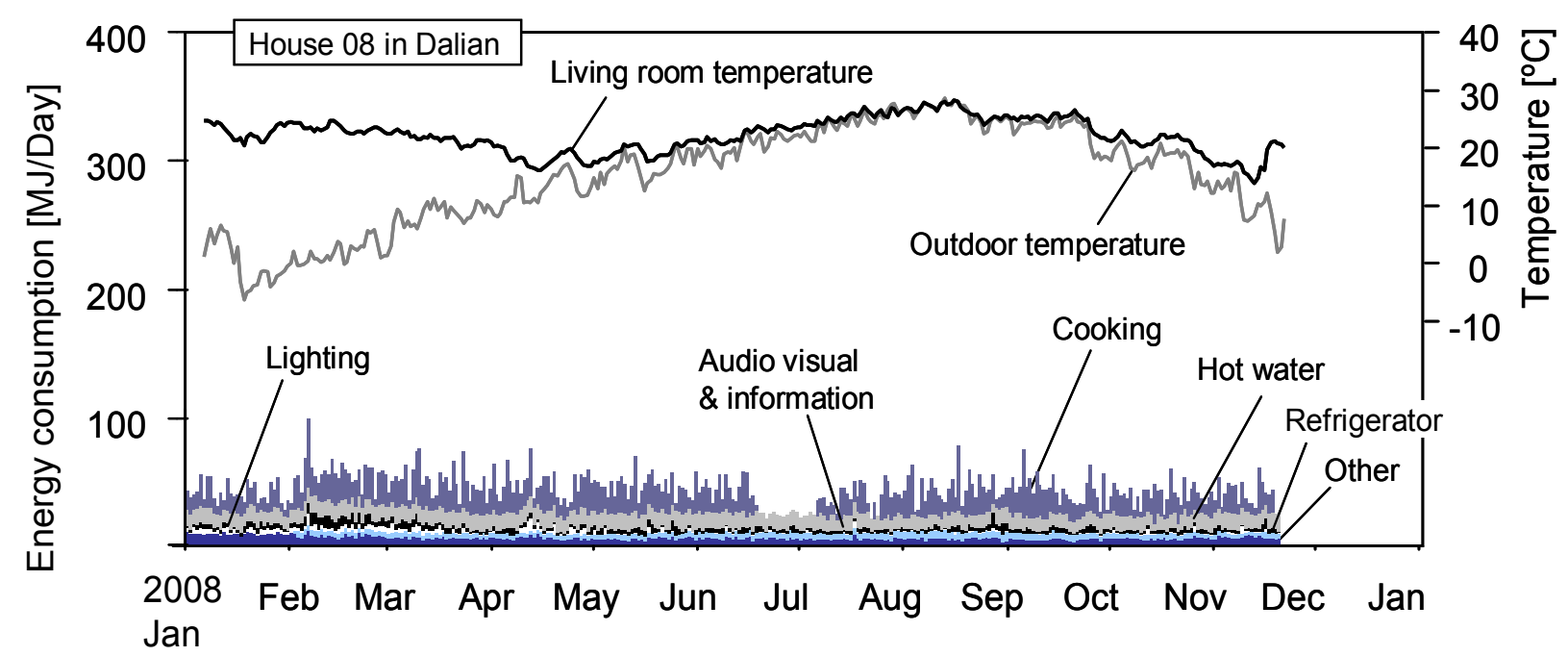

(c)

\subsubsection{House 01}

House 01 used space heating mainly in January, and space cooling mainly in July and August. It can be seen that the energy uses of space cooling was high when the outside temperature was above $30^{\circ} \mathrm{C}$. The cooling use was higher than heating. No major energy use changes on refrigerators, lighting, audio visual \& information were found throughout the year. The energy used for the refrigerator in summer is slightly more than that in winter. It is because the energy use of refrigerator has a correlation with the indoor temperature. The gas energy use in winter was higher than in other seasons because in winter, the occupants used hotter water for bathing and longer time for cooking which consumes more gas than in summer, in addition, the temperature of tap water is lower in winter than summer. A major change in indoor temperatures was found. The indoor temperature also changed due to the use of heating and cooking during winter and summer. The average indoor and outdoor temperature in summer was about $30{ }^{\circ} \mathrm{C}$. The average indoor and outdoor temperatures in winter were about $15^{\circ} \mathrm{C}$ and $5{ }^{\circ} \mathrm{C}$, respectively.

\subsubsection{House 05}

The heating was used from November to February, and the heating uses were high when the outside temperature was below $0{ }^{\circ} \mathrm{C}$. Gas use (heating and cooking $\&$ hot water) was the largest among the three houses, and the peak value reached $318 \mathrm{MJ} /$ day on January 24th (heating and cooking \& hot water used $269 \mathrm{MJ} /$ day and $12 \mathrm{MJ} /$ day, accounted for $96 \%$ and $4 \%$ of the total energy use respectively in the day).

The indoor temperature in winter kept at around $20{ }^{\circ} \mathrm{C}$ because the heating was used, while the outdoor temperature was below $8{ }^{\circ} \mathrm{C}$. There is a slight difference of temperature between indoors and outdoors in summer when cooling was used. 


\subsubsection{House 08}

The each end use of energy use did not differ much throughout the year. The space cooling was not used in summer since the typical summer weather in Dalian is generally comfortable, and energy usage for cooling is not necessary. The difference of energy use on refrigerator cannot be found since the indoor temperature almost kept at $26{ }^{\circ} \mathrm{C}$ in a year. The average indoor temperature was maintained constantly above $26{ }^{\circ} \mathrm{C}$ in winter because of the use of district heating, although the outdoor temperature was below $5{ }^{\circ} \mathrm{C}$. The indoor temperature was the same as the outdoor temperature in summer.

\subsection{Energy Use in the Coldest Month, Hottest Month and the Month of Mild Season}

Figure 6 shows different energy use amounts in the coldest months (winter), the hottest months (summer) and the months of the mild season (spring) of three houses.

Figure 6. Energy use in the month of winter, spring and summer.

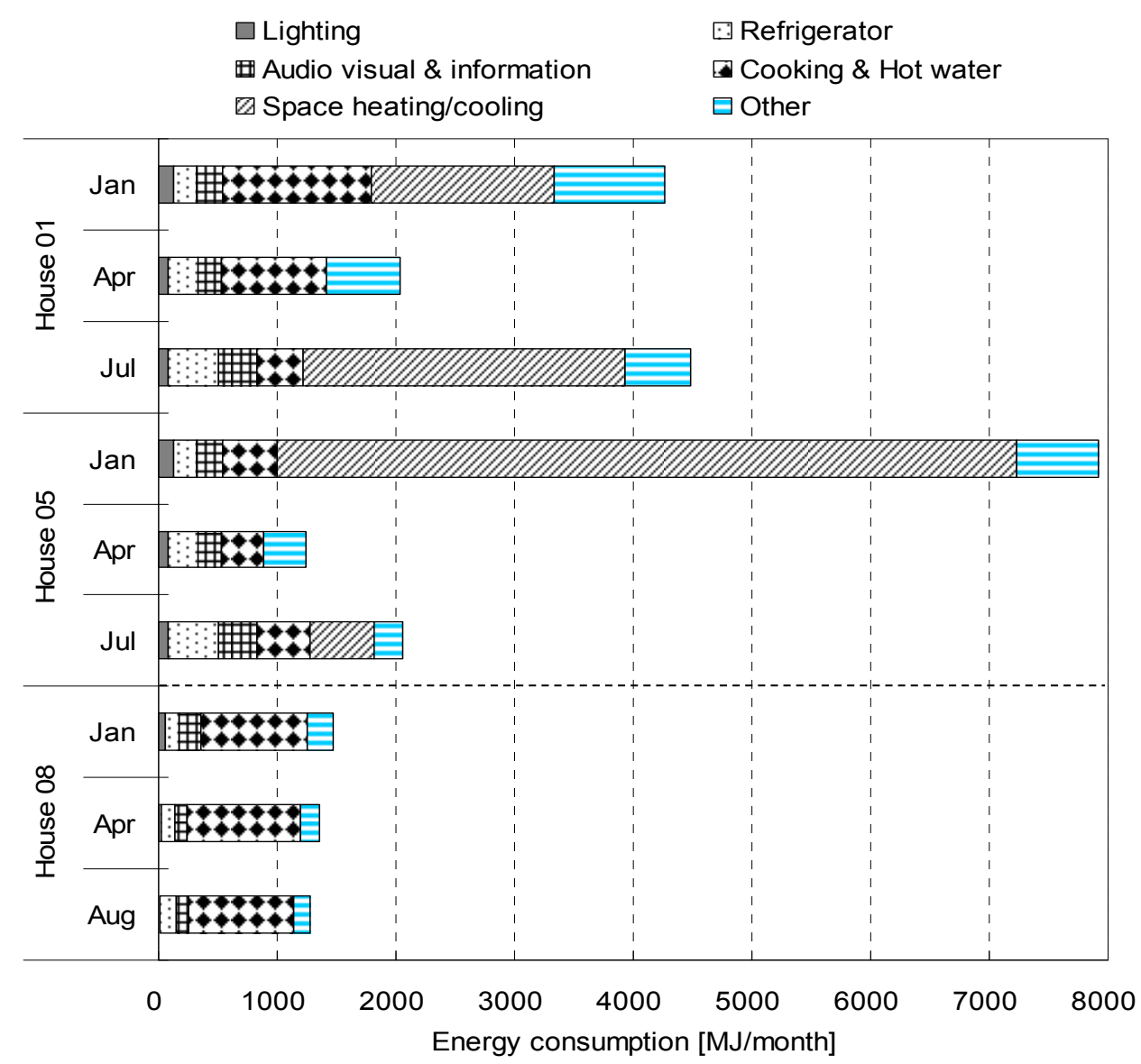

\subsubsection{House 01}

The energy use in January and July was more than that in April, respectively. The energy use of cooking \& hot water in January (1249 MJ) was higher than in July (881 MJ) and April (394 MJ). In January, $65 \%$ of the total energy was used for space heating, hot water \& cooking. In July, $61 \%$ of the 
total energy was used for space cooling. It is clear that cooling use was more than heating use. The energy used for hot water in January was more than that in other months.

\subsubsection{House 05}

House 05 used $6234 \mathrm{MJ}$ for space heating in January, which accounted for $79 \%$ of the total energy use, and used $540 \mathrm{MJ}$ for cooling in July, which accounted for $26 \%$ of the total energy. The energy use in January was almost four times and seven times that in August and April, respectively.

\subsubsection{House 08}

The total energy use and energy distribution proportion in each season was not very different. The energy used for cooking \& hot water was the largest in the total energy use, accounting for $70 \%$ of the total energy use. It can be seen that the energy use of lighting was also not much different in winter, spring and summer. The energy used for lighting accounts for a very small part in the total energy use.

\subsection{Energy Consumption and Thermal Environment in Typical Days}

The energy uses and temperatures during three days in winter and summer are shown in Figures 7 and 8 , respectively. The midday is the coldest/hottest art of the day with the lowest/highest outdoor air temperature during the investigation period. Each diagram of Figures 7 and 8 is divided into two parts: the upper half shows the space heating/cooling uses, gas consumption and others, as well as the temperatures of outdoor air, living room and bedroom, while the lower half describes the uses of lighting, audio visual $\&$ information and refrigerator. The energy use was shown for an interval of 30 minutes.

\subsubsection{Energy Use and Temperature in the Coldest Day}

Figure 7 shows the energy consumption of these three houses on the coldest day, and the days before and after the coldest day. The energy uses of district heating, district hot water and solar hot water heater are not included. Regarding House 01, the heating use was mainly in the morning (6:00 AM-7:30 AM) and in the evening (17:00 PM-21:00 PM), and the peak of energy use appeared at around 18:30 PM on January 3rd (the day before the hottest day) with a value of $37 \mathrm{MJ} /$ hour. At that time, the occupants used electricity for space heating and gas for hot water supply $\&$ cooking. The temperatures of bedroom and living room remained around $13{ }^{\circ} \mathrm{C}$ to $14{ }^{\circ} \mathrm{C}$, except during the heating hours.

For House 05, the heating (using gas) was operated for 24 hours a day, and the peak use appeared at around 12:30 PM when the heating and cooking was used at same time on January 22nd (the day before the hottest day) with a value of $98 \mathrm{MJ} /$ hour which is the largest among the three houses. The average temperature of the living room in the three days was $17^{\circ} \mathrm{C}$.

The heating use of House 08 was not known, however, judging from the fact that the room temperature was maintained at $26^{\circ} \mathrm{C}$ although the outdoor temperature was below $5{ }^{\circ} \mathrm{C}$, it was deduced that central heating was in use throughout the day. The energy use peaks were found only at cooking hours. Because House 08 used district heating throughout the day, the room temperature was 
maintained at $26{ }^{\circ} \mathrm{C}$, although the outdoor temperature was below $0{ }^{\circ} \mathrm{C}$. There is about a $10{ }^{\circ} \mathrm{C}$ difference between House 01 and Houses 05 and 08.

Figure 7. Energy use and temperature in three days in winter (a) House 01; (b) House 05; (c) House 08 .

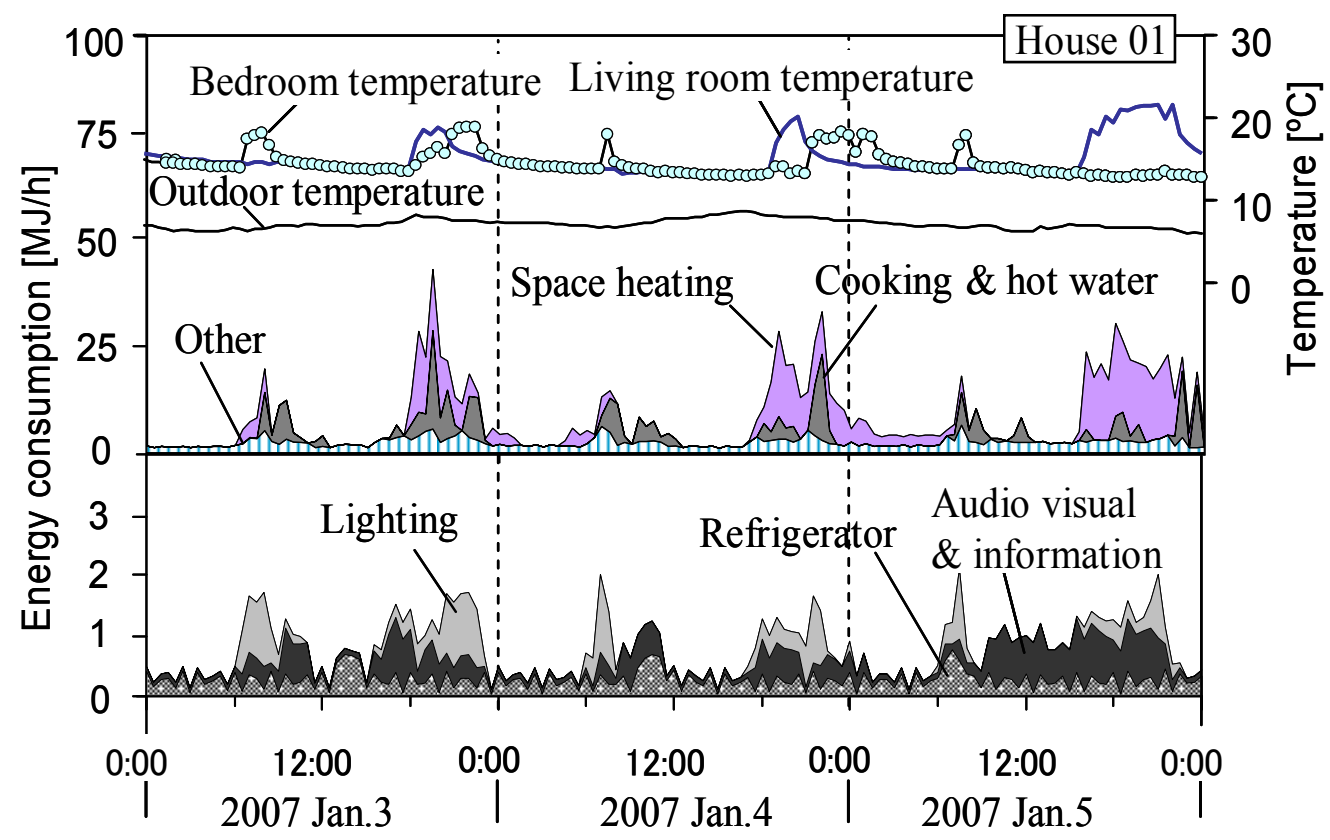

(a)

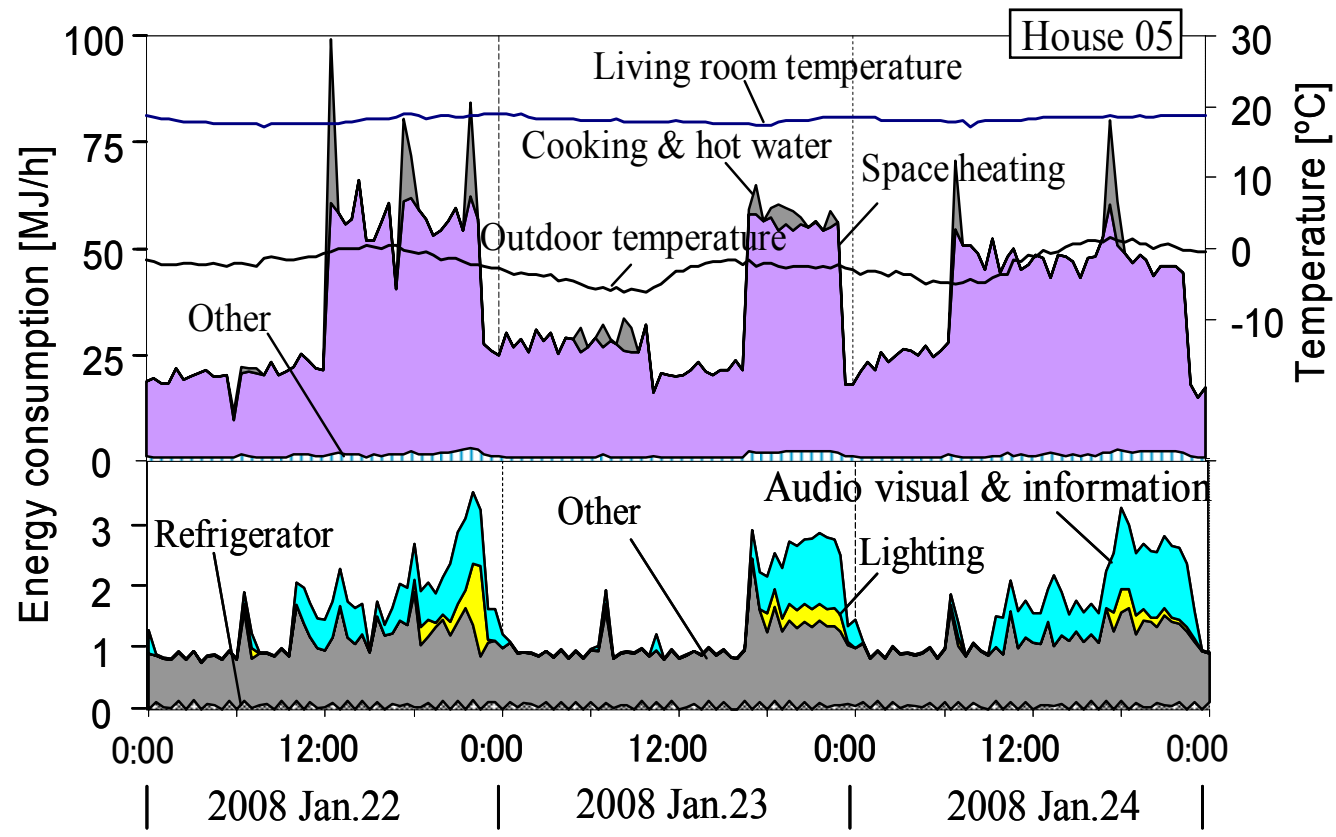

(b) 
Figure 7. Cont.

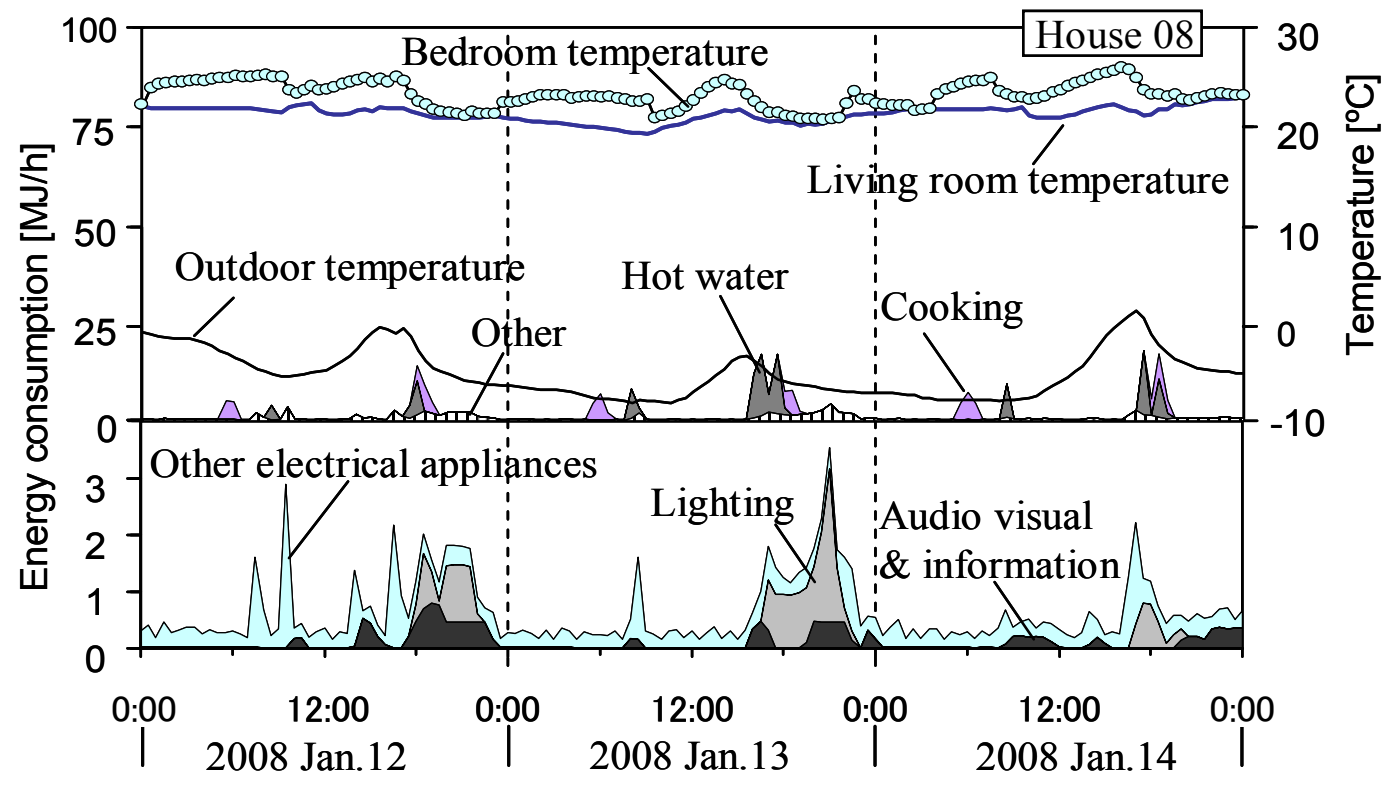

(c)

\subsubsection{Energy Consumption and Temperature in the Hottest Day}

Figure 8 shows the energy use of these three houses on the hottest day, and the days before and after the hottest day.

Figure 8. Energy use and temperature in three days in summer (a) House 01; (b) House 05; (c) House 08 .

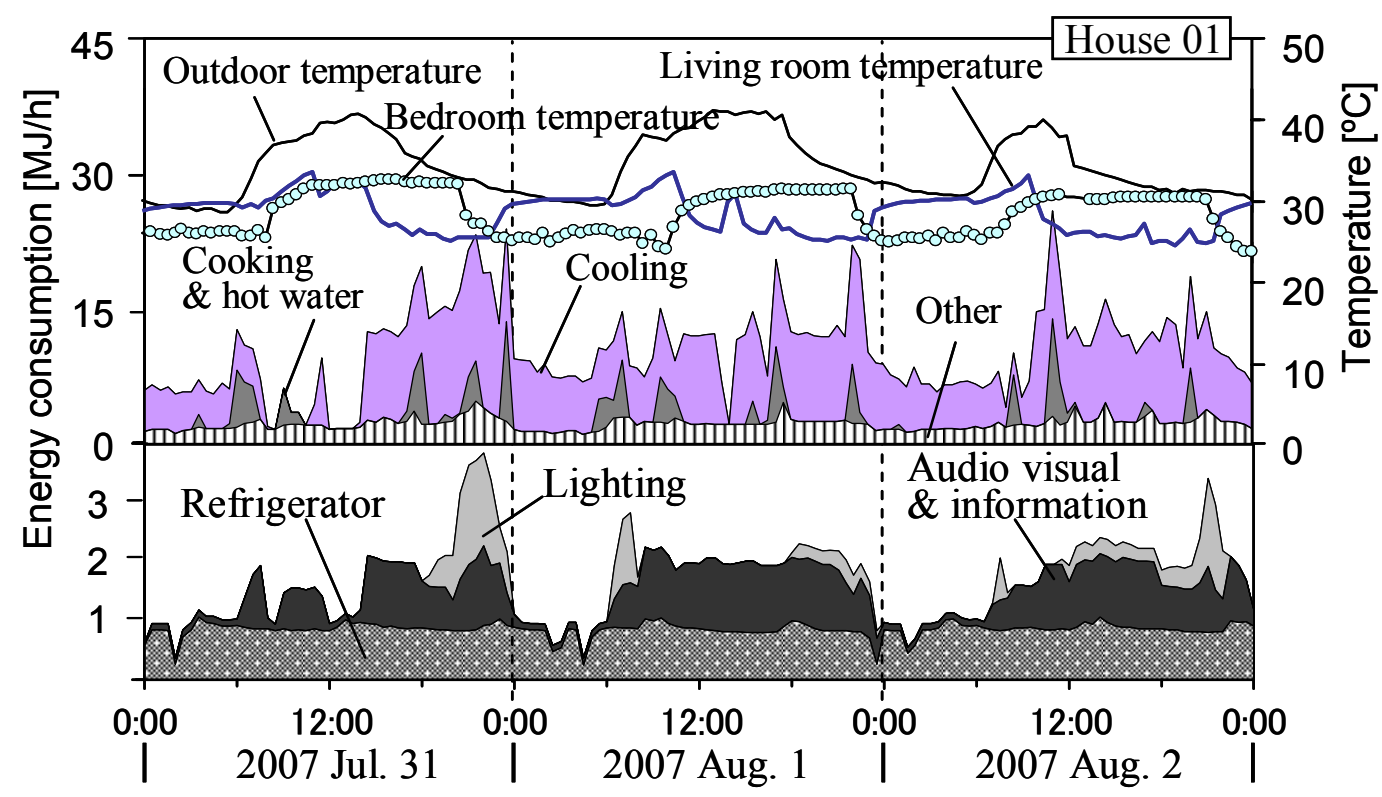

(a) 
Figure 8. Cont.

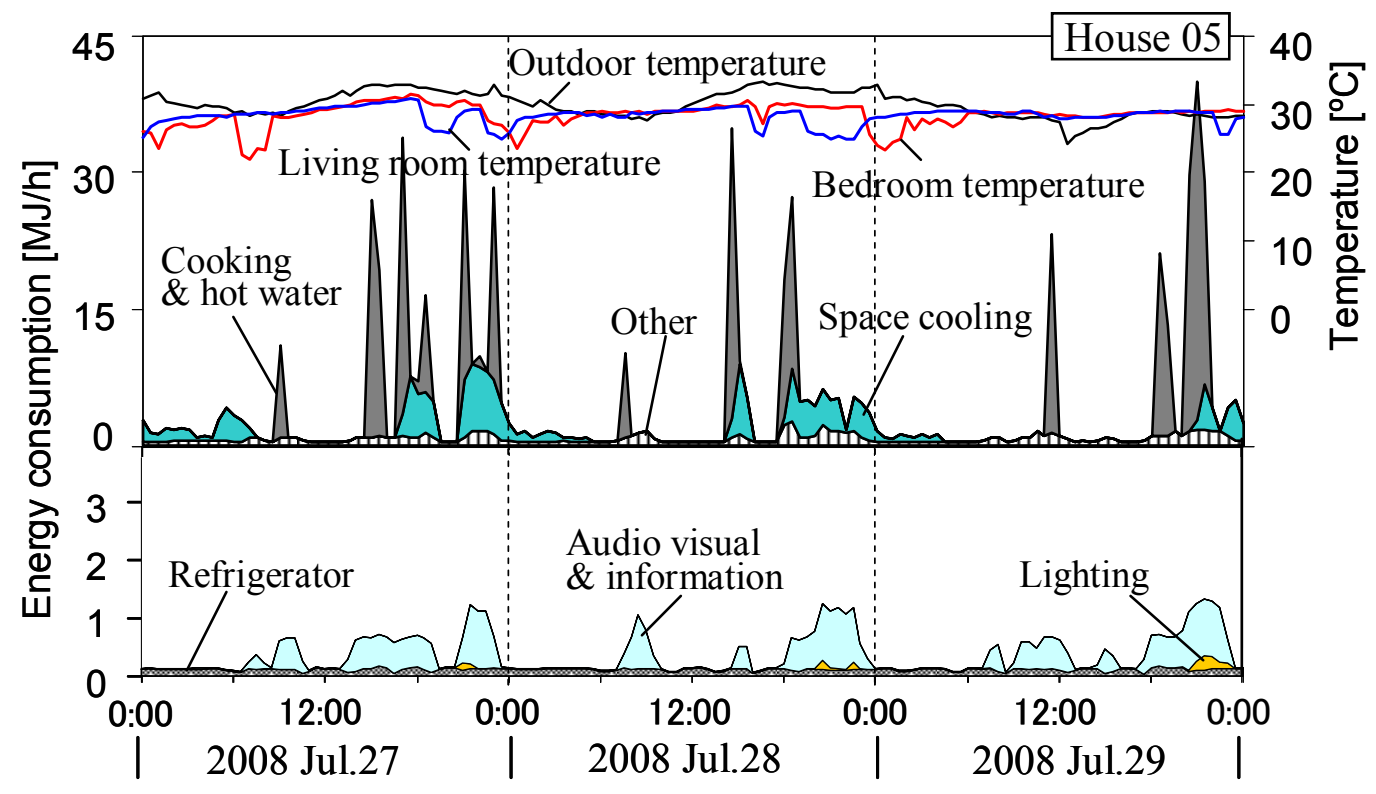

(b)

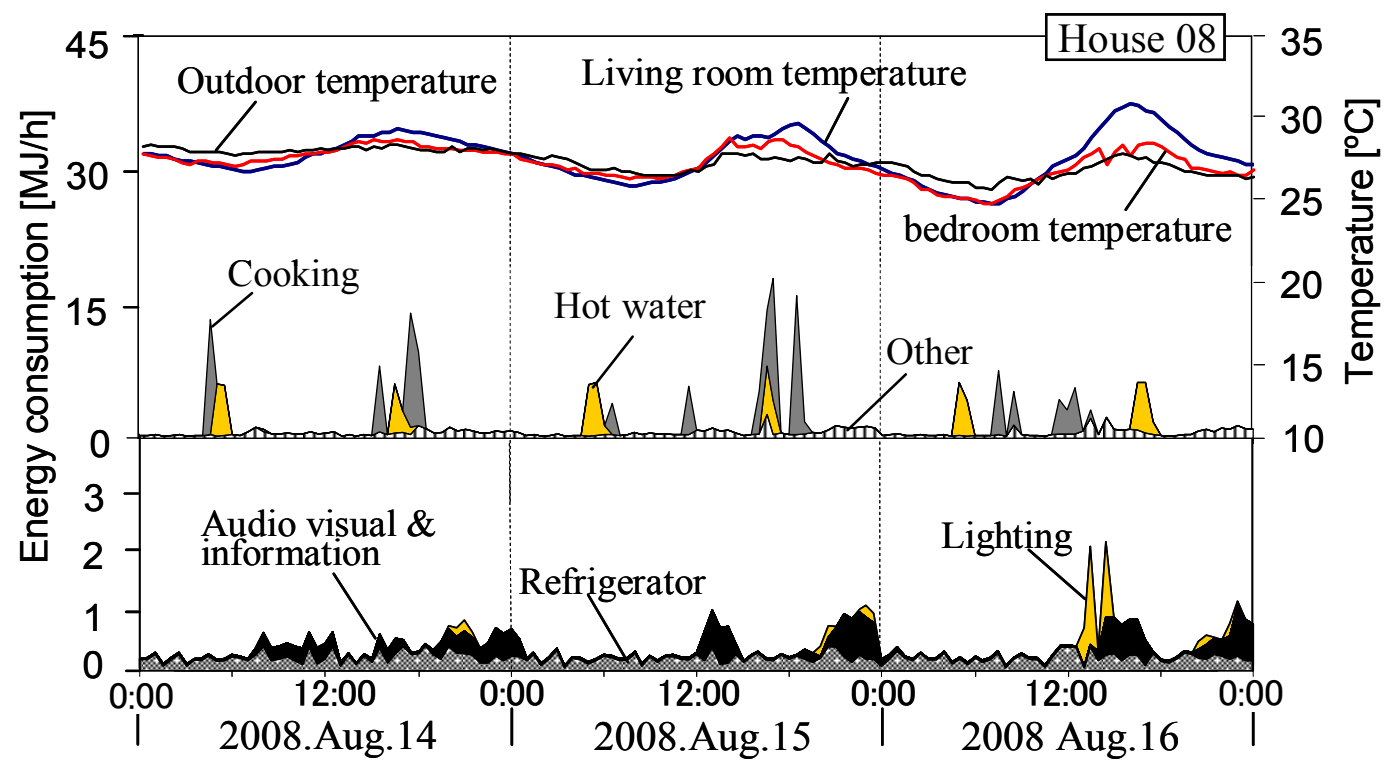

(c)

For House 01, several energy use peaks were found in a day due to the use of space cooling and gas for hot water \& cooking. The peak use value was $28 \mathrm{MJ} /$ hour which appeared at around 11:00 AM on August 2 when cooling and gas was used for cooking $\&$ hot water at same time. Living room and bedroom temperatures decreased to around $25{ }^{\circ} \mathrm{C}$ when the air-conditioning was operated, but returned to $30^{\circ} \mathrm{C}$ when the air-conditioning was not used.

In House 05, space cooling was used several times during occupied hours. The peak use was due to cooking. The peak use value was $40 \mathrm{MJ} /$ hour at around 21:00 $\mathrm{PM}$ on the night on July 29 , which is the largest among the three houses. Living room and bedroom temperatures were around $25{ }^{\circ} \mathrm{C}$ when cooling was used, but returned to almost $29{ }^{\circ} \mathrm{C}$ when air-conditioning was not used. 
House 08 did not use any air-conditioning equipment since the temperature is comfortable in summer. The use peak appeared during cooking hours. Living room and bedroom temperatures were maintained around $27^{\circ} \mathrm{C}$. There are no significant indoor temperature differences between indoors and outdoors.

\subsection{Discussion}

Daily energy use of 12 houses for a year in three zones is analyzed in this paper. From Figure 4, it was found that energy used for hot water accounts for a large part in the total energy use. A solar water heater helps to save energy. Combined with Figures 5 and 6, it was found that energy use for lighting, audio \& information and refrigerator in Houses 01,05 and 08 was not much different during the four seasons and they accounted for a small part of the total energy use.

In Group 2, energy use for district heating could not be measured. The research with questionnaire and simulation method done by $\mathrm{Yu}$ et al. [12] showed the equation how to calculate the energy used for district heating of household. Based on that equation with a parameter of floor area in Beijing, Dalian and Shenyang, the energy used for district heating in Houses 06, 07, 08, 09 and 10 was calculated, and they will be 40.8, 57.2, 50.2, 87.5 and $79.6 \mathrm{GJ} / \mathrm{year}$, and the total annual energy of Houses 06, 07, 08, 09, 10 will be 52.3, 60.1, 64.4, 104.5 and 85.6 GJ respectively. Each of them is larger than the largest one (House 05) in Group 1. The energy use of House 09 was 3.2 times of average energy use in Japan (45 GJ/household) [13].

From Figure 7, it was found that central heating was used thought the day by occupants in House 08 even while the apartment is empty. It is a big issue that large amounts of heat are wasted. In the very cold zone and the cold zone where district heating is widespread, there are large district heating areas of nearly 6.5 billion $\mathrm{m}^{2}$. Space heating in north of China uses a large part of the total energy use of residential buildings in China and there is large energy-saving potential in this area [14].

The daily energy use of five houses with domestic heating and seven houses with district heating in six cities was analyzed. The detailed characteristics were obtained. However, the important factors influencing energy consumption are not easy to understand comprehensively since the sample size is not large, thus, larger-scale field measurements in each city are necessary for the future study.

\section{Conclusions}

The energy use for end use, indoor and outdoor air temperature has been investigated in these twelve houses located in six cities of China. The energy use and thermal environment in daily life are analyzed. Though the number of houses is not large, some preliminary conclusions can be drawn as follows:

(1) Detailed information of energy use and indoor environment in twelve houses are obtained. There is a big difference of energy use between houses due to different kind of housing equipment used and different occupant behavior of energy use.

(2) Energy use of houses in Group 1 increased in winter and summer. This is attributed to the use of heating in winter and cooling in summer. House 05 in Beijing used 32.4 GJ in a year (the largest in Group 1), in which the heating reached $18.5 \mathrm{GJ}$, accounting for $57 \%$ of the total consumption. 
(3) In Group 2, energy use for district heating can not be measured. House 09 consumed 17.0 GJ, which is the largest in Group 2. It was estimated that the total energy use (including energy used for district heating) will be 104.5 GJ.

(4) There are no significant changes of Lighting, Audio visual \& information, and other energy use among the four seasons.

(5) A big difference of average indoor temperature was found in the coldest days between Group 1 and Group 2. Indoor temperature of Group 1 and Group 2 was around $10{ }^{\circ} \mathrm{C}$ and $20{ }^{\circ} \mathrm{C}$, respectively.

\section{Acknowledgements}

This research is supported under the project of Grant-in-Aid for Scientific Research from the Ministry of Education, Culture, Sports, Science and Technology of Japan. The authors would like to give many thanks to the academics, students and practitioners who have helped us, including the Department of College of Mechanical Engineering, Tongji University; College of Civil Engineering, Hunan University; School of Municipal and Environmental Engineering, Harbin Institute of Technology; Department of Building Science School of Architecture, Tsinghua University and so on. Special thanks are given to the residents who assisted and coordinated our investigation.

\section{References}

1. National Bureau of Statistics. China Statistical Yearbook 2010; China Statistics Press: Beijing, China, 2011.

2. Zhao, L.; Li, N.; Ma, C. Residential energy consumption in urban China: A decomposition analysis. Energy Policy 2012, 41, doi:101016/j.enpol.2011,11.027.

3. Zhou, N.; Nishida, M.; Gao, W. Current Status and Future Scenarios of Residential Building Energy Consumption in China; Lawrence Berkeley National Laboratory: Berkeley, CA, USA, 2008; 2416E.

4. Chen, S.; Yoshino, H.; Li, N. Statistical analyses on summer energy consumption characteristics of residential buildings in some cities of China. Energy Build. 2010, 42, 136-146.

5. Yoshino, H.; Yoshino, Y.; Zhang, Q.; Mochida, A.; Li, N.; Li, Z.; Miyasaka, H. Indoor thermal environment and energy saving for urban residential buildings in China. Energy Build. 2006, 38, 1308-1319.

6. Yoshino, H.; Lou, H. Indoor thermal environment of residential buildings in three cities of China. J. Asian Archit. Build. Eng. 2002, 1, 129-136.

7. Yoshino, H.; Jiang, Z.; Li, Z.; Li, N.; Liu, J.; Lu, W.; Pei, Q.; Zhen, J.; Zhu, Y. Investigation of Urban Residential Energy Consumption in China. In Proceedings of the First International Conference on Building Energy and Environment, Dalian, China, 4-6 August 2008; pp. 284-291.

8. Lam, J.C. An analysis of residential sector energy use in Hong Kong. Energy 1996, 21, 1-8.

9. Yoshino, H.; Guan, S.; Lun, Y.; Shigeno, T; Yoshino, Y.; Zhang, Q. Summer survey on indoor thermal environment of urban residential buildings in China. J. Asian Archit. Build. Eng. 2002, 1, $65-72$. 
10. Zhang, H.; Yoshino, H. Analysis of indoor humidity environment in residential buildings. Build. Environ. 2010, 45, 2132-2140.

11. Department of Construction of the PRC. Thermal Design Code for Civil Buildings; China Plan Press: Beijing, China, 1993; GB50176-93.

12. Yu, Liang; Watanabe, T.; Yoshino, H.; Gao, W. Research on energy consumption of urban apartment buildings in China [In Japanese]. J. Environ. Eng. 2008, 73, 183-190.

13. The Energy Data and Modeling Center Handbook of Energy \& Economic Statistics in Japan; The Energy Conservation Center: Tokyo, Japan, 2006.

14. Jiang, Y. Current building energy consumption in China and effective energy efficiency measures. Heat. Vent. Air Cond. 2005, 35, 30-40.

(C) 2012 by the authors; licensee MDPI, Basel, Switzerland. This article is an open access article distributed under the terms and conditions of the Creative Commons Attribution license (http://creativecommons.org/licenses/by/3.0/). 